\title{
ANALYSIS OF RESEARCH TRENDS IN PRODUCTION OF SOLID BIOFUELS
}

\section{Adrian Knapczyk, Slawomir Francik, Jaroslaw Fraczek, Zbigniew Slipek}

University of Agriculture in Krakow, Poland

adrian.knapczyk91@gmail.com, slawomir.francik@urk.edu.pl, fraczek.ur@gmail.com

\begin{abstract}
Solid biofuels can be defined as processed and unprocessed biomass. By definition it can be divided into: natural fuels (as obtained) and synthetic fuels (after mechanical and chemical treatment). Raw materials for the production of solid biofuels may include: wood, stalk plants, peat, sewage sludge and grains of cereals. These raw materials can be used directly as fuel or as a half-finished product for further production. The aim of the work was to analyze trends and research topics in the production of solid biofuels. This analysis was made using bibliometric techniques. Bibliometric analyzes allow to indicate the research topics, authors, as well as research institutions that significantly influence a given discipline. The research and analysis were carried out on scientific articles taken from the Scopus database in 2014-2018. The downloaded data have been cleaned and processed in the VOSviewer program. This program allows to analyze the frequency of occurrence of keywords in years and to present results in graphic form. Next, a detailed analysis of the content of the publications and classification according to selected criteria was carried out. The main countries that carry out research in this area are: Spain, Italy, Brazil, the Czech Republic and China. The main research areas were: Energy, Environmental Science, Agricultural and Biological Sciences, Chemical Engineering and Engineering. The most popular research topics throughout the research period were: biomass (raw materials, properties), biomass agglomeration processes (briquetting, pelleting), energy properties research, thermal biomass treatment (torrefaction, gasification and others), research on production and biochar properties and other.
\end{abstract}

Keywords: bibliometric analysis, research trends, scientometric, literature review, solid biomass.

\section{Introduction}

Biofuels can be divided into solid, liquid and gas. In terms of production, they show both the characteristics of agricultural production (cultivation of energy crops, harvest of raw materials, etc.) and industrial (processing of raw materials).

Solid biofuels can be defined as processed and unprocessed biomass. By definition, it can be divided into: natural fuels (as obtained) and synthetic fuels (after mechanical and chemical treatment). Raw materials for the production of solid biofuels may include: wood, stem plants, peat, sewage sludge and cereal grains. These raw materials can be used directly as fuel or as an intermediate for further production (Table 1) [1].

Table 1

Division of solid biofuels [1]

\begin{tabular}{|c|c|c|}
\hline Group & Raw material & Type of biofuel \\
\hline \multirow{4}{*}{1} & Sawdust, shavings & Poodlets, briquettes \\
\cline { 2 - 3 } & $\begin{array}{c}\text { Fast growing trees (willow, poplar), branches } \\
\text { from pruning bushes and trees }\end{array}$ & $\begin{array}{c}\text { Wood chips, cylindrical and rectangular bales } \\
\text { of various sizes }\end{array}$ \\
\cline { 2 - 3 } & Trunks, thick branches & Wood blocks, wood chips, pieces of wood \\
\cline { 2 - 3 } & Waste wood & Wood blocks, wood chips, pieces of wood \\
\hline \multirow{2}{*}{2} & Stem plants (cereal straw, miscanthus, etc.) & $\begin{array}{c}\text { Pellets, briquettes, cylindrical and rectangular } \\
\text { bales of various sizes, chaff, loose material }\end{array}$ \\
\hline 3 & Peat & Pellets, briquettes \\
\hline 4 & Sewage sludge & Pellets, briquettes, granules \\
\hline 5 & Wheat seeds & Grain \\
\hline
\end{tabular}

Numerous studies are carried out to determine the physical and chemical properties of solid biofuels, their agglomeration and subjecting them to various thermal processes [2-8]. Therefore, it is necessary to determine the main directions of the research in the field of solid biofuel production.

An intensive increase in the development of science forces scientists to learn about the current research trends in a given area of science, eg. solid biofuels. This knowledge allows to learn about the research topics and to plan the research. Keeping track of the current research trends allows you to familiarize yourself with the latest discoveries, compare the research scopes, etc. Many authors 
confirm the legitimacy of performing such analyzes. Bibliometric analyzes are used in the analysis of the research trends [9-13].

Bibliometric analysis allows to perform statistical analyzes of publications, organizations, people and many others. The analysis based on bibliometric data is currently very widely used. It allows quantitative analyzes to be carried out objectively. Data for analyzes are codified, ordered and come from global scientific publication databases, eg. Web of Science, Scopus and others. Bibliometry is an important tool for determining the research trends [14].

The purpose of the work was to determine the main topics and research trends in the production of solid biofuels. The bibliometric analysis method is used.

\section{Materials and methods}

A modified bibliometric analysis method is proposed by Knapczyk et al. [14]. The following stages of analysis were adopted.

1. Identifying documents in the Scopus database for the category "Article title, Abstract, Keywords": "Solid biofuel*"; type of document: "article", period: 2014-2018.

2. Uploading all publications in the analysed period of time and extracting bibliometric data (authors, title, abstract, year of issue, key words, additional key words, publishing house).

3. Construction and analysis of term maps (VOSviewer software).

4. Identifying the most frequently found key words in the analysed period of time.

Bibliometric analyses were performer with the use of the freeware, VOSviewer. This program is used for creating and graphic visualisation of bibliometric maps. VOSviewer utilized the method of "visualization of similarities" VOS [15].

\section{Results and discussion}

In the examined period, 234 documents were analysed in total (according to Scopus database). The authors come from Spain (26 documents), Italy ( 24 doc.), Brazil (23 doc.), the Czech Republic (19 doc.) and China (14 doc.). In the analyzed period the documents were in the research areas: Energy (97 doc.), Environmental Science (78 doc.), Agricultural and Biological Sciences (67 doc.), Chemical Engineering (63 doc.) and Engineering (62 doc.).

In the next stage, the most frequently occurring key words were determined for the analysed periods. For each period the analysis of all key words (Author Key words, Index Key words) was performed (VOS Viewer). The results of the simulations are presented in Fig. 1.

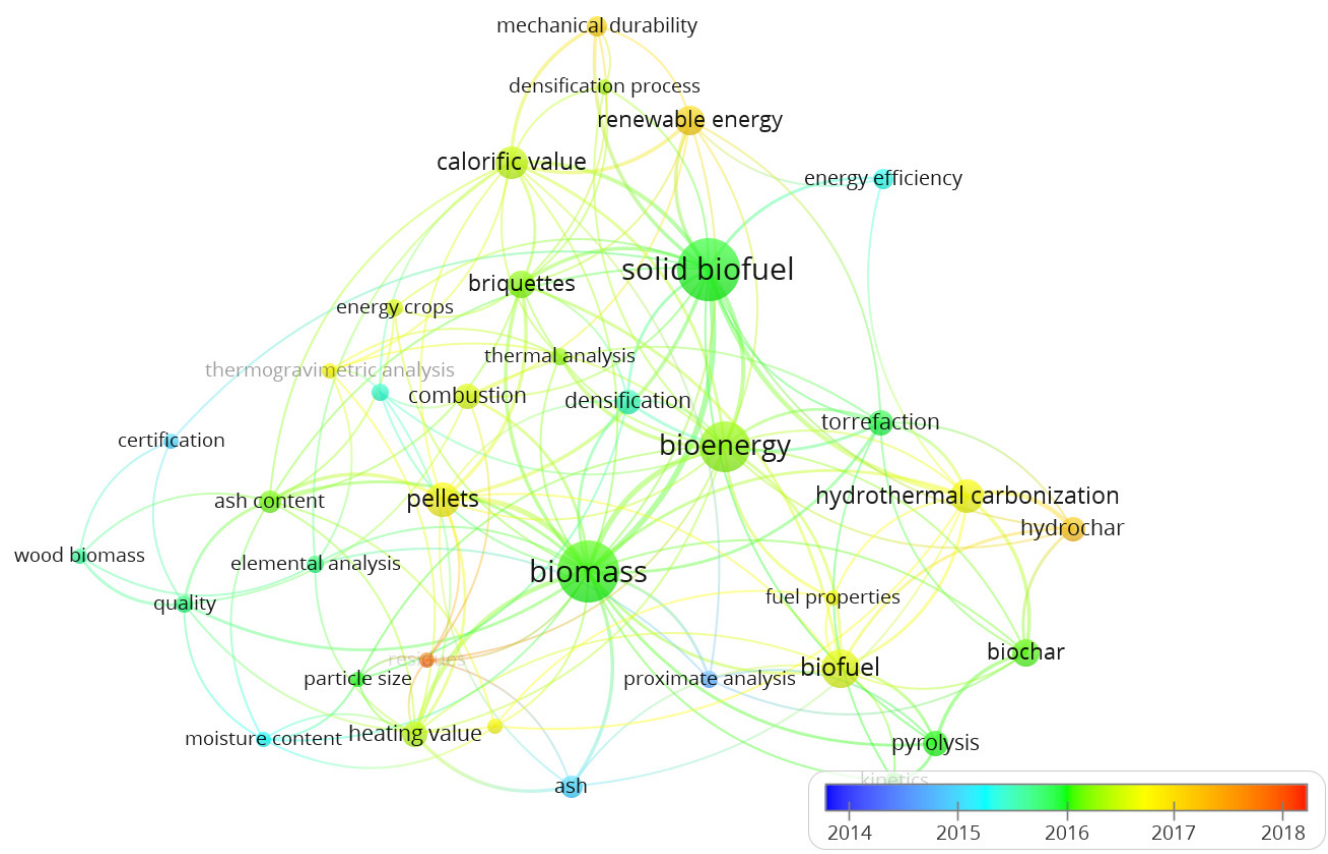

Fig. 1. Map of terms: occurrence of keywords in particular years of publishing 
Result of the topic analysis of publications in 2018

\begin{tabular}{|c|c|}
\hline THEME GROUPS & SUBJECTS DISCUSSED (the last/most current sample documents) \\
\hline $\begin{array}{l}\text { I. New raw materials } \\
\text { for the production } \\
\text { of solid biofuels }\end{array}$ & $\begin{array}{l}\text { - The use of various biological materials for energy purposes: } \\
\text { 1. human excreta [16] } \\
\text { 2. mixtures of biofuels with industrial waste (eg. tires) }[17 ; 18] \\
\text { 3. waste biomass after palm oil [19] } \\
\text { 4. biomass from guava (Psidium guajava } \text { L.) }[20] \\
\text { 5. sunflower husks [21] } \\
\text { 6. peanut shells [22] } \\
\text { 7. bamboo fiberandsugarcane skin [23] } \\
\text { 8. mixtures of biomass with plastics [24] } \\
\text { 9. waste from processing Mango (Mangifera indica } \text { L.) [25] } \\
\text { 10. waste from vines [26] } \\
\text { 11. MD2 pineapple [27] }\end{array}$ \\
\hline $\begin{array}{l}\text { II. Logistics, economic } \\
\text { and legal analysis }\end{array}$ & $\begin{array}{l}\text { - Multi-dimensional model of production and logistics of biomass [28] } \\
\text { - Impact of wind energy use in RES [29] } \\
\text { - Economic analysis of agglomeration processes (pelletising and } \\
\text { briquetting) [30] } \\
\text { - Use ofsolid biofuels in Mexico [31] } \\
\text { - Development of an intelligent logistics system for managing the biomass } \\
\text { supply chain [32] } \\
\text { - Legal analysis of the international standard classification of solid } \\
\text { biofuels [33] } \\
\text { - Development of an identification system to ensure the quality of biomass } \\
\text { pruning for the production of solid biofuels [34] }\end{array}$ \\
\hline $\begin{array}{c}\text { III. The torrefaction } \\
\text { process }\end{array}$ & $\begin{array}{l}\text { - Hydrothermal carbonizationwaste-wood mixtures, mixtures of peat moss } \\
\text { and miscanthusand waste from the wine industry [21;35;36] } \\
\text { - Biomass torrefaction (energy plants, olive pomace, etc.) [37-43] }\end{array}$ \\
\hline $\begin{array}{l}\text { IV. Properties and } \\
\text { cultivation of } \\
\text { biological raw } \\
\text { materials }\end{array}$ & $\begin{array}{l}\text { - Cultivation Sida hermaphrodita (L.) Rusby [44] } \\
\text { - Impact of planting rhizomes on the development, productivity, etc. in } \\
\text { miscanthus [45] } \\
\text { - Determining the calorific value, chemical composition of elements and } \\
\text { main thermo-energetic parameters in wood and bark of fast-growing } \\
\text { deciduous tree species and other types of biomass [46-49] }\end{array}$ \\
\hline $\begin{array}{l}\text { V. Agglomeration } \\
\text { process }\end{array}$ & $\begin{array}{l}\text { - Assessment of physico-mechanical properties of agglomeratesand the } \\
\text { effect of added biochar and bio-oil, waste from recycled paperon these } \\
\text { properties [50-53] } \\
\text { - Study the briquetting process of Schizolobium parahyba (guapuruvu) } \\
\text { [54] } \\
\text { - Assessment of waste potential after biodiesel production,from soybean } \\
\text { cultures, sugar caneand eucalyptus wood, invasive plants, waste of } \\
\text { macauba fruitto agglomeration process [55-59] }\end{array}$ \\
\hline VI. Other & $\begin{array}{l}\text { - Analysis of the composition of the atmosphere in Indian farms during } \\
\text { the combustion process [60] } \\
\text { - The use of analytical toolsin the analysis of data from laboratory analysis } \\
\text { of alternative and solid biofuels [61] } \\
\text { - The use of models based on weather datato estimate the moisture content } \\
\text { of wood in forests[62] }\end{array}$ \\
\hline
\end{tabular}


Figure 1 shows a summary of keywords according to the period of publication. The main research topics in particular sections were completed: 2014-2016 - "ash", "energy efficiency", "proximate analysis", "certification" moisture content", "wood biomass", "chemical composition", densification" "solid biofuel", "biomass", "bioenergy", "torrefaction", "briquettes", "biochar", "pyrolysis", "ash content", "palletization"; 2016-2018 - "calorific value", "higher heating value", "hydrothermal carbonization", "energy crops", "hydrochar", "renewable energy", "mechanical durability". In the first period, the main research areas were research on the agglomeration process, pyrolysis, energy properties (ash content, energy efficiency, etc.), selected biomass properties. In the second period, the greatest interest of researchers was enjoyed by studies of the energy properties (heat of combustion, calorific value) of biological raw materials, hydrothermal carbonization process and testing properties biochar and hydrochar.

As part of the qualitative analysis, documents from the last analysis period were analyzed (Tab. 2). Of the 234 documents, 50 were published in 2018. Due to the impossibility of reaching full Texas, 2 publications were excluded from the analysis. On the basis of abstracts and content, the publications were divided into 6 thematic groups, namely (Tab. 2.): I - new raw materials for the production of solid biofuels; II - logistics, economic and legal analysis; III - torrefaction process; IV properties and cultivation of biological raw materials; V - agglomeration process; VI - other. Within the first group (12 publications), the topics discussed included the study of biological raw materials, mainly of vegetable origin, for energy purposes. In the second group (7 publications), the authors addressed topics related to logistics (biomass production and logistics model, intelligent logistic system, IT identification system, etc.) as well as economic and legal analyzes of renewable energy sources. The third group (10 publications) included publications dealing with the subject matter of dry and wet torrefaction as well as properties of biochar from different materials. In the fourth group (6 publications) the authors addressed topics such as growing energy crops and testing selected energy properties of biological raw materials. The fifth group (10 publications) contained documents that were thematically related to the process of biomass agglomeration (pelleting, briquetting) and the effect of additions on this process. In the last sixth group ( 3 publications) there were documents that did not fit thematically to any of the groups mentioned above. These documents mainly concerned modeling and atmospheric composition testing in the combustion process in households.

\section{Conclusions}

1. The conducted bibliometric analysis allowed to indicate the decision problems concerning the production of solid biofuels. These problems mainly concern the search for new biological raw materials for energy applications, the torrefaction process, hydrothermal carbonization and the agglomeration process.

2. Two trends are noticeable, firstly, increasing the importance of processed solid biofuels (pellets, briquettes, biochar, hydrochar and others), and secondly, looking for new raw materials that can be used alone or as additives to commonly used raw materials.

\section{Acknowledgements}

This research was financed by the Ministry of Science and Higher Education of the Republic of Poland (statutory activities DS-3600/WIPiE/2018, Faculty of Production and Power Engineering, University of Agriculture in Krakow).

\section{References}

[1] Zbytek Z., Adamczyk F. Possibility of solid biomass use. Part 1. Legal regulations and division of solid biomass. Tech. Rol. Ogrod. Leśna, no. 2, 2017, pp. 26-28.

[2] Mudryk K., Fraczek J., Wrobel M., Jewiarz M. Pressure agglomeration herbaceous raw materials intended for consumer purposes./ 17th International Scientific Conference "Engineering for Rural Development". Jelgava, 23-25 May 2018, pp. 771-776.

[3] Niemczyk M., Kaliszewski A., Jewiarz M., Wróbel M., Mudryk K. Productivity and biomass characteristics of selected poplar (Populus spp.) cultivars under the climatic conditions of northern Poland. Biomass and Bioenergy, vol. 111, 2018, pp. 46-51. 
[4] Mierzwa-Hersztek M., Gondek K., Jewiarz M., Dziedzic K. Assessment of energy parameters of biomass and biochars, leachability of heavy metals and phytotoxicity of their ashes. J. Mater. Cycles Waste Manag., 2019, https://doi.org/10.1007/s10163-019-00832-6.

[5] Kubica K., Jewiarz M., Kubica R., Szlęk A. Straw Combustion: Pilot and Laboratory Studies on a Straw-Fired Grate Boiler," Energy \& Fuels, vol. 30, no. 6, 2016, pp. 4405-4410.

[6] Wróbel M., Mudryk K., Jewiarz M., Głowacki S., Tulej W. Characterization of Selected Plant Species in Terms of Energetic Use. Springer, Cham, 2018, pp. 671-681.

[7] Jewiarz M., Mudryk K., Wrobel M., Pociask A., Agglomeration of dried ilex paraguariensis for consumption purposes./ 17th International Scientific Conference "Engineering for Rural Development". Jelgava, 23-25 May 2018, pp. 1593-1598.

[8] Wrobel M., Mudryk K., Jewiarz M., Knapczyk A. Impact of raw material properties and agglomeration pressure on selected parmeters of granulates obtained from willow and black locust biomass./ 17th International Scientific Conference "Engineering for Rural Development". Jelgava, 23-25 May 2018, pp. 1933-1938.

[9] Lei L., Liu D. The research trends and contributions of System's publications over the past four decades (1973-2017): A bibliometric analysis. System, vol. 80, 2019, pp. 1-13.

[10] Yu D., Xu Z., Fujita H. Bibliometric analysis on the evolution of applied intelligence. Appl. Intell., vol. 49, no. 2, 2019, pp. 449-462.

[11]Bojović S., Matić R., Popović Z., Smiljanić M., Stefanović M., Vidaković V. An overview of forestry journals in the period 2006-2010 as basis for ascertaining research trends. Scientometrics, vol. 98 , no. 2, 2014, pp. 1331-1346.

[12] Hernández J. B., Chalela S. Research Trends in the Study of ICT Based Learning Communities: A Bibliometric Analysis. EURASIA J. Math. Sci. Technol. Educ., vol. 13, no. 5, 2016, pp. 15391562.

[13] Magrí A., Giovannini F., Connan R., Bridoux G., Béline F. Nutrient management from biogas digester effluents: a bibliometric-based analysis of publications and patents. Int. J. Environ. Sci. Technol., vol. 14, no. 8, 2017, pp. 1739-1756.

[14] Knapczyk A., Francik S., Pedryc N., Hebda T. Bibliometric analysis of research trends in engineering for rural development./ 17th International Scientific Conference "Engineering for Rural Development". Jelgava, 23-25 May 2018, pp. 700-707.

[15] van Eck N. J., Waltman L. Software survey: VOSviewer, a computer program for bibliometric mapping. Scientometrics, vol. 84, no. 2, 2010, pp. 523-538.

[16] Yahav Spitzer R., Mau V., Gross A. Using hydrothermal carbonization for sustainable treatment and reuse of human excreta. J. Clean. Prod., vol. 205, 2018, pp. 955-963.

[17] Aljbour S. H. Catalytic pyrolysis of olive cake and domestic waste for biofuel production. Energy Sources, Part A Recover. Util. Environ. Eff., vol. 40, no. 23, 2018, pp. 2785-2791.

[18] Pontes R., Romaní A., Michelin M., Domingues L., Teixeira J., Nunes J. Comparative autohydrolysis study of two mixtures of forest and marginal land resources for co-production of biofuels and value-added compounds. Renew. Energy, vol. 128, 2018, pp. 20-29.

[19]Brunerová A., Müller M., Šleger V., Ambarita H., Valášek P. Bio-Pellet Fuel from Oil Palm Empty Fruit Bunches (EFB): Using European Standards for Quality Testing. Sustainability, vol. 10, no. 12, 2018, p. 4443.

[20] Ivanova T., Mendoza Hernández A., Bradna J., Fernández Cusimamani E., García Montoya J., Armas Espinel D. Assessment of Guava (Psidium Guajava L.) Wood Biomass for Briquettes' Production. Forests, vol. 9, no. 10, 2018 p. 613.

[21] Wang T. et al. Evaluation of the clean characteristics and combustion behavior of hydrochar derived from food waste towards solid biofuel production. Bioresour. Technol., vol. 266, 2018, pp. 275-283.

[22] Perea-Moreno M.-A., Manzano-Agugliaro F., Hernandez-Escobedo Q., Perea-Moreno A.-J. Peanut Shell for Energy: Properties and Its Potential to Respect the Environment. Sustainability, vol. 10, no. 9, 2018, p. 3254.

[23] Brunerová A., Roubík H., Brožek M. Bamboo Fiber and Sugarcane Skin as a Bio-Briquette Fuel. Energies, vol. 11, no. 9, 2018, p. 2186. 
[24] Madadian E., Akbarzadeh A. H., Lefsrud M. Pelletized Composite Wood Fiber Mixed with Plastic as Advanced Solid Biofuels: Thermo-Chemical Analysis. Waste and Biomass Valorization, vol. 9, no. 9, 2018, pp. 1629-1643.

[25] Perea-Moreno A.-J., Perea-Moreno M.-Á., Dorado M. P., Manzano-Agugliaro F. Mango stone properties as biofuel and its potential for reducing CO2 emissions. J. Clean. Prod., vol. 190, 2018, pp. 53-62.

[26] Pizzi A. et al. Emissions of heating appliances fuelled with agropellet produced from vine pruning residues and environmental aspects. Renew. Energy, vol. 121, 2018, pp. 513-520.

[27] Mansor A. M., Lim J. S., Ani F. N., Hashim H., Ho W. S. Ultimate and Proximate Analysis of Malaysia Pineapple Biomass from MD2 Cultivar for Biofuel Application. Chem. Eng. Trans., vol. 63, 2018, pp. 127-132.

[28] Vávrová K., Knápek J., Weger J., Králík T., Beranovský J. Model for evaluation of locally available biomass competitiveness for decentralized space heating in villages and small towns. Renew. Energy, vol. 129, 2018, pp. 853-865.

[29] Ramírez F. J., Honrubia-Escribano A., Gómez-Lázaro E., Pham D. T. The role of wind energy production in addressing the European renewable energy targets: The case of Spain. J. Clean. Prod., vol. 196, 2018, pp. 1198-1212.

[30] Czekała W. et al. The energy value and economic efficiency of solid biofuels produced from digestate and sawdust," Energy, vol. 159, 2018, pp. 1118-1122.

[31] Tauro R., Serrano-Medrano M., Masera O. Solid biofuels in Mexico: a sustainable alternative to satisfy the increasing demand for heat and power. Clean Technol. Environ. Policy, vol. 20, no. 7 , 2018, pp. 1527-1539.

[32] Gebresenbet G., Bosona T., Olsson S.-O., Garcia D. Smart System for the Optimization of Logistics Performance of the Pruning Biomass Value Chain. Appl. Sci., vol. 8, no. 7, 2018, p. 1162.

[33]Zanetti M., Greco R., Costa C., Cavalli R. Changes of particle size classification of wood chips according to the new standard rules for domestic use. Eur. J. Wood Wood Prod., vol. 76, no. 2, 2018, pp. 805-807.

[34] Bosona T., Gebresenbet G., Olsson S.-O. Traceability System for Improved Utilization of Solid Biofuel from Agricultural Prunings. Sustainability, vol. 10, no. 2, 2018, p. 258.

[35] Roy P., Dutta A., Gallant J. Hydrothermal Carbonization of Peat Moss and Herbaceous Biomass (Miscanthus): A Potential Route for Bioenergy. Energies, vol. 11, no. 10, 2018, p. 2794.

[36] Basso D., Weiss-Hortala E., Patuzzi F., Baratieri M., Fiori L. In Deep Analysis on the Behavior of Grape Marc Constituents during Hydrothermal Carbonization. Energies, vol. 11, no. 6, 2018, p. 1379.

[37] Grottola C. M., Giudicianni P., Michel J. B., Ragucci R. Torrefaction of Woody Waste for Use as Biofuel. Energy \& Fuels, vol. 32, no. 10, 2018, pp. 10266-10271.

[38] Ramos-Carmona S., Martínez J. D., Pérez J. F. Torrefaction of patula pine under air conditions: A chemical and structural characterization. Ind. Crops Prod., vol. 118, 2018, pp. 302-310.

[39] Viotto R. S., Maia A. A. D., Yamaji F. M., de Morais L. C. Thermogravimetric investigation of spent shiitake substrate to solid biofuel. Can. J. Chem. Eng., vol. 96, no. 4, 2018, pp. 845-854.

[40] Mihajlović M. et al. Hydrothermal carbonization of Miscanthus $\times$ giganteus : Structural and fuel properties of hydrochars and organic profile with the ecotoxicological assessment of the liquid phase. Energy Convers. Manag., vol. 159, 2018, pp. 254-263.

[41] Gultekin S. Y., Olgun H., Celiktas M. S. Comparison of solid biofuels produced from olive pomace with two different conversion methods: torrefaction and hydrothermal carbonization. Int. J. Eng. Technol., vol. 7, no. 2.23, 2018, p. 143.

[42] Volpe M., Goldfarb J. L., Fiori L. Hydrothermal carbonization of Opuntia ficus-indica cladodes: Role of process parameters on hydrochar properties. Bioresour. Technol., vol. 247, 2018, pp. 310318.

[43] Garcia D. P., Caraschi J. C., Ventorim G., Vieira F. H. A., Protásio T. D. P. Comparative Energy Properties of Torrefied Pellets in Relation to Pine and Elephant Grass Pellets. BioResources, vol. 13, no. 2, 2018, pp. 2898-2906. 
[44]Bilandžija N., Krička T., Matin A., Leto J., Grubor M. Effect of Harvest Season on the Fuel Properties of Sida hermaphrodita (L.) Rusby Biomass as Solid Biofuel. Energies, vol. 11, no. 12, 2018, p. 3398.

[45] Vakhnyi S., Khakhula V., Fedoruk Y., Grabovskyi M., Herasymenko L., Mykhaylivna Karpuk L. Miscanthus productivity formation for biofuel production that depending of differs on density of standingplants. Plant Arch., vol. 18, no. 2, 2018, pp. 1920-1924.

[46] Chin K. L. et al. Additional additives to reduce ash related operation problems of solid biofuel from oil palm biomass upon combustion. Ind. Crops Prod., vol. 123, 2018, pp. 285-295.

[47] Musule R. et al. Growing up at Different Altitudes: Changes in Energy Content of the Abies religiosa Wood. BioEnergy Res., vol. 11, no. 1, 2018, pp. 209-218.

[48] Vasiliki K., Charalampos L., Panagiotis B. Utilization of wood and bark of fast-growing hardwood species in energy production. J. For. Sci., vol. 64, no. No. 4, 2018, pp. 164-170.

[49] Vitázek I., Majdan R., Mojžiš M. Volatile combustible release in biofuels. Agron. Res., vol. 16, no. 5, 2018, pp. 2229-2241.

[50] Brunerová A., Brožek M., Šleger V., Nováková A. Energy Balance of Briquette Production from Various Waste Biomass. Sci. Agric. Bohem., vol. 49, no. 3, 2018, pp. 236-243.

[51] Kang K. et al. Codensification of Eucommia ulmoides Oliver stem with pyrolysis oil and char for solid biofuel: An optimization and characterization study. Appl. Energy, vol. 223, 2018, pp. 347357.

[52] Matúš M., Križan P., Šooš L., Beniak J. The effect of papermaking sludge as an additive to biomass pellets on the final quality of the fuel. Fuel, vol. 219, 2018, pp. 196-204.

[53] Chaloupková V., Ivanova T., Ekrt O., Kabutey A., Herák D., Determination of Particle Size and Distribution through Image-Based Macroscopic Analysis of the Structure of Biomass Briquettes. Energies, vol. 11, no. 2, 2018, p. 331.

[54] Narita D. K., Nakashima G. T., da Róz A. L., Pires A. A. F., Yamaji F. M. Use of schizolobium parahyba for energy purposes. Ciência Florest., vol. 28, no. 2, 2018, p. 758.

[55] Miranda M. T., Sepúlveda F. J., Arranz J. I., Montero I., Rojas C. V. Physical-energy characterization of microalgae Scenedesmus and experimental pellets. Fuel, vol. 226, 2018, pp. 121-126.

[56] Scatolino M. V. et al. Options for Generation of Sustainable Energy: Production of Pellets Based on Combinations Between Lignocellulosic Biomasses. Waste and Biomass Valorization, vol. 9, no. 3, 2018, pp. 479-489.

[57]Zihare L., Soloha R., Blumberga D. The potential use of invasive plant species as solid biofuel by using binders. Agron. Res., vol. 16, no. 3, 2018, pp. 923-935.

[58] Chiteculo V., Brunerová A., Surový P., Brožek M. Management of Brazilian hardwood species (Jatoba and Garapa) wood waste biomass utilization for energy production purposes. Agron. Res., vol. 16, 2018, pp. 365-376.

[59] Teixeira V. L., Carneiro A. D. C. O., Evaristo A. B., Homem de Faria B. D. F., Donato D. B., De Magalhães M. A. POTENTIAL OF MACAUBA EPICARP (Acrocomia aculeata (Jacq.) Lodd. ex Martius) FOR BRIQUETTES PRODUCTION. FLORESTA, vol. 48, no. 4, 2018, p. 563.

[60] Nayek S. Padhy P. K. Approximation of personal exposure to fine particulate matters (PM2.5) during cooking using solid biomass fuels in the kitchens of rural West Bengal, India. Environ. Sci. Pollut. Res., vol. 25, no. 16, 2018, pp. 15925-15933.

[61] Sajdak M. Kotyczka-Morańska M. Development and validation of a fast method based on infrared spectroscopy for biochar quality assessment. Biomass and Bioenergy, vol. 112, 2018, pp. 99-109.

[62] Lindblad J., Routa J., Ruotsalainen J., Kolström M., Isokangas A., Sikanen L. Weather based moisture content modelling of harvesting residues in the stand. Silva Fenn., vol. 52, no. 2, 2018, pp. 1-16. 